Die mikroskopischen Boden-Pilze :

ihr Leben, ihre Verbreitung sowie ihre öconomische und pathogene Bedeutung. Von Dr. Anneliese Niethammer. Pp. vi $+193+6$ plates. ('s-Gravenhage : Dr. W. Junk, 1937.) 13 florins.

$\mathrm{T}$ is always a gratifying stage in the development $\mathcal{L}$ of any department of science, when a large number of detailed investigations can be collected, correlated, and woven into a coherent philosophy of the subject as a whole. That stage has arrived in the study of soil mycology, and the monograph under review is worthy of the occasion. Literature upon the taxonomy of microscopic fungi which live in the soil has been comparatively unavailable. Dr. Niethammer's work collects it, and the mycologist whose studies have not bitherto been specifically related to pedology may now find his way with relative ease amongst the Phycomycetes, Ascomycetes and Fungi Imperfecti which provide the microscopic fungus flora of the soil.

The second part of the monograph reviews the distribution of these organisms in relation to worldwide geographical and climatic conditions, to soil types, and to the higher plants which grow thereon. This leads to a discussion of the life-histories of fungi under natural conditions, their pathology and chemical action upon various substances in the soil. Modern conceptions of growth-regulating substances are reviewed mycologically, whilst the relation of soil fungi to the practice of manuring is also discussed. Many new correlations are here possible, and a large amount of such information is included in the 73 quarto pages of detailed stocktaking which follow the 100 pages of taxonomy. The shortening of some generic names to their initial is sometimes disconcerting, whilst the further criticism of the paucity of plates and drawings is only emphasized by the high quality of the six which are included.

J. G.

\section{The Conservation of Prints, Drawings and Manu-} scripts

By Dr. H. J, Plenderleith. (Published for the Museums Association.) Pp. vii $+66+5$ plates. (London : Oxford University Press, 1937.) 3s. 6d. net.

7 HIS is the second member of a series of booklets issued by the Museums Association with the general idea of helping curatiors in their task of conservation of precious objects. It may be said at once that this purpose is admirably fulfilled by the pages now before us.

The scheme is, first to consider the nature of the materials in question-paper, parchment, inks and so forth-and then to discuss methods for cleaning and repair. Both physical and chemical processes are involved in this work. The crux of the whole matter is experience. Given that experience, a very modest equipment will enable it to be utilized to the full. The value of this manual is that it is the product of profound experience, presented in such a way that others may benefit from it, even if their resources are more limited than those at the author's disposal. A number of good illustrations are included.

F. I. G. R.
Electricity and Magnetism :

an Introduction to the Mathematical Theory. By A. S. Ramsey. Pp. xi +267 . (Cambridge: At the University Press, 1937.) 10s. 6d.

"VIEILLE école, bonne école, hey ?" said Major Pendennis, and the remark is irresistibly suggested by the contents and scope of a work which "covers the schedule for Part I of the Tripos", untouched and undismayed by the drums and tramplings of one knows not how many conquests. Here the student will find an old story admirably retold, and he who would learn to deal effectively with such problems as demand a good working knowledge of Laplace's equation, the method of images, distribution in networks of conductors, selfand mutual-inductance and the like, will find the president of Magdalene's volume an efficient and trustworthy guide. He will have much more to learn before he arrives at the confines of modern knowledge of electricity, but he will have nothing to unlearn, and a careful study of the book will provide him with knowledge likely to be of great help in his later studies.

A. F.

\section{Brompton Hospital Reports :}

a Collection of Papers recently published from the Hospital. Vol. 6. Pp. iv $+183+6$ plates. (London : Research Department, Brompton Hospital, 1937.) $2 s$. $6 d$.

$\mathrm{N}$ addition to three hitherto unpublished articles 1 dealing respectively with multiple cystic disease of the lungs by Drs. F. H. Young and N. C. Oswald, an investigation of the relation of bronchography to post-lobectomy atelectasis by Mr. R. H. R. Belsery, and an investigation on statistical lines of the clinical aspects of senile phthisis by Drs. W. D. W. Brooks and F. P. Lee Lander, this volume contains papers which have been published elsewhere on perspective and poise in practice, and various aspects of pulmonary tuberculosis and other diseases of the chest. The index of authors for the first six volumes and the subject index for the first five are included. The annual report of the Hospital for 1937 is appended.

\section{German for Students of Medicine and Science :} with Notes, Grammatical Introduction and Vocabulary. By W. F. Mainland. Pp. xlvii +160. (Edinburgh and London: Oliver and Boyd, n.d.) $8 s .6 d$. net.

7 HIS useful work is intended to relieve the irksomeness of learning German for the already overworked undergraduate, medical practitioner or lecturer in a medical school, who should welcome the unconventional method adopted. The book contains an indispensable minimum of grammar, a short list of German medical journals and a selection of passages from medical and lay writers, classified as easy, moderately difficult and advanced, and dealing with anatomy, histology, physiology, biochemistry, pathology and bacteriology, medicine, pharmacology, surgery, hygiene and dietetics, psychology and the history of medicine. A vocabulary is provided. 